\title{
Triple Bottom Line: A Look at Talent Acquisition and Employee Engagement Using Grounded Theory
}

\author{
Hanan Alhaddi ${ }^{1, *}$ \\ ${ }^{1}$ Lawrence Technological University, Southfield, MI, USA \\ *Correspondence: Lawrence Technological University, Southfield, MI, USA. E-mail: halhaddi@ford.com
}

Received: September 12, 2014

Accepted: September 26, $2014 \quad$ Online Published: October 13, 2014

doi:10.5430/mos.v2n1p25

URL: http://dx.doi.org/10.5430/mos.v2n1p25

\begin{abstract}
This paper is based on a study that explored triple bottom line (TBL) as an emerging phenomenon using grounded theory. Presented here are the results from the section concerning talent acquisition and employee engagement of the original study. The presented results suggest that TBL Image (a term developed in the study) is positively associated with talent acquisition and employee engagement. This is illustrated by the introduction of the TBL Image Diagram, which provides an insight into how the image of the organization (as TBL-oriented) enables it to attract (and retain) talent and improve employee engagement. This paper contributes to sustainability scholarship by presenting new findings regarding TBL (as a sustainability-related construct) using grounded theory in light of the lack of empirical research on TBL in the related literature. The study also contributes to human resource scholarship by providing new insight into new elements that influence talent acquisition and employee engagement. Practitioners in human resource management benefit from this study as the findings further their understanding of how to influence the organization from an employee perspective through the TBL lens.
\end{abstract}

Keywords: triple bottom line; talent acquisition; employee engagement; grounded theory; sustainability

\section{Introduction}

TBL is a sustainability-related construct that was coined by Elkington (1997). Driven by sustainability, TBL provides a framework for measuring the performance of the business and the success of the organization using three spaces: environment, society, and economy (Goel, 2010). The term TBL has been referred to as the practical framework of sustainability (Rogers \& Hudson, 2011). Targeted toward corporations, the TBL agenda places a consistent and balanced emphasis on the economic, social, and environmental areas simultaneously. The economic line of TBL framework refers to the impact of the organization's business practices on the economic system. The economic line ties the growth of the organization to the growth of the economy and how well it contributes to support it. The social line of TBL refers to conducting beneficial and fair business practices to the labor, human capital, and to the community (Elkington, 1997). The idea is that these practices provide value to the society and "give back" to the community. The environmental line of TBL refers to engaging in practices that do not compromise the environmental resources for future generations. It pertains to the efficient use of energy recourses, reducing greenhouse gas emissions, and minimizing the ecological footprint, etc. (Goel, 2010).

In essence, TBL expresses the expansion of the environmental agenda in a way that integrates the economic and social lines (Elkington, 1997). In his definition of TBL, Elkington used the terms profit, people, and the planet as the three lines. In this study, the environmental, social, and economic lines referred to planet, people, and profit respectively. Unlike the extensive scholarship on other sustainability-related constructs like sustainable development and corporate social responsibility (CSR), little empirical research has been done on TBL. Driven by the literature gap, this study set out to further the understanding of TBL by focusing on image as a tool for differentiation. The study established the term TBL Image and used it to refer to the image of the organization as one that is TBL-driven/oriented. 


\section{Research Method and Grounded Theory}

Qualitative approach is best suited when a phenomenon has not been explored yet, which demonstrates the value of qualitative research in enabling the researcher to develop constructs (Marshall \& Rossman, 2006). In this case, TBL as an emerging phenomenon needs to be explored further in order to understand its influence on the organization. The discovery of grounded theory as a strategy for qualitative research is credited to Glaser and Strauss (1967). Grounded in data, Glaser and Strauss suggested that "generating grounded theory is a way of arriving at theory suited to its supposed uses" (p.3). The grounded theory process presented by Charmaz (2006) was followed in this study (see Table 1).

Table 1. Grounded Theory Process

\begin{tabular}{|c|c|}
\hline Grounded Theory Process by Charmaz (2006) & Process of this Study (original study) \\
\hline $\begin{array}{l}\text { Formulation of research problem and research } \\
\text { questions }\end{array}$ & $\begin{array}{l}\text { Objective of the research was to understand the influence of TBL } \\
\text { on strategic positioning. The main research question: how does } \\
\text { TBL influence strategic positioning within a global organization? } \\
\text { Research sub-questions: } \\
\text { 1-What does TBL mean to the organization? } \\
\text { 2-How does the organization use TBL to differentiate its strategic } \\
\text { position in the market? } \\
\text { 3-How does the organization incorporate TBL into its image? }\end{array}$ \\
\hline Generation of initial coding and data collection & $\begin{array}{l}\text { Raw data generated } 260 \text { double space pages. A total of 1,327 open } \\
\text { codes were generated. Data collection was done using feedback } \\
\text { from } 23 \text { in-depth interviews with participants from Johnson } \\
\text { Controls. Data also obtained from printed and electronic media } \\
\text { sources. }\end{array}$ \\
\hline $\begin{array}{l}\text { Drafting initial memos and raising codes to } \\
\text { tentative categories }\end{array}$ & $\begin{array}{l}\text { Seven initial memos were written that captured the impressions } \\
\text { and reflection of the researcher. }\end{array}$ \\
\hline Data collection and focused coding & $\begin{array}{l}\text { Data collection continued. Open codes were developed into } 38 \\
\text { categories using axial coding. }\end{array}$ \\
\hline $\begin{array}{l}\text { Writing advanced memos and refining of } \\
\text { conceptual categories }\end{array}$ & $\begin{array}{l}\text { Twenty advanced memos were written to capture and refine } \\
\text { specific categories. }\end{array}$ \\
\hline $\begin{array}{l}\text { Theoretical sampling (seeking specific new } \\
\text { data) }\end{array}$ & $\begin{array}{l}\text { Theoretical sampling was used to obtain new and specific data } \\
\text { related to social investors and shareholders. }\end{array}$ \\
\hline $\begin{array}{l}\text { Converting certain categories into theoretical } \\
\text { constructs and further refining of constructs }\end{array}$ & $\begin{array}{l}\text { Categories developed through axial coding were converted into } \\
\text { theoretical constructs. }\end{array}$ \\
\hline Sorting memos & $\begin{array}{l}\text { Final count of memos was } 27 \text {. Memos were sorted according to } \\
\text { the relative categories to reinforce/confirm the researcher's } \\
\text { understanding of the theoretical constructs. }\end{array}$ \\
\hline $\begin{array}{l}\text { Integrating memos and diagramming } \\
\text { constructs }\end{array}$ & $\begin{array}{l}\text { Memos were integrated into the data analysis. Developed } \\
\text { constructs were diagrammed }\end{array}$ \\
\hline Writing the first draft & First draft of study was written. \\
\hline
\end{tabular}




\subsection{Unit of Analysis and Participant (Subject) Characteristics}

Johnson Control, a Fortune 500 organization with a TBL approach was used as the unit of analysis in the study. Johnson Controls is a global leader and supplier for automotive components, building efficiency systems, and power (battery) solutions. Utilizing the TBL approach, Johnson Controls promotes economic, social, and environmental practices that benefit the local communities, shareholders, customers, and employees. Research participants were identified using purposeful sampling. Participants (employees of the organization) were divided into groups based on the organizational rank, level of responsibility in strategic planning, and expertise in TBL and sustainability. Therefore, the list of participants included vice presidents of the three groups (Building Efficiency, Automotive Experience, and Power Solutions), directors of strategic planning, strategic planning managers, vice presidents and managers in sustainability, vice presidents and directors of public affairs and communications, and all members of the Global Environment and Sustainability Council (GESC). Participants were selected using purposeful, snowball, and theoretical sampling. A total of 23 in-depth interviews were conducted via conference calls. Purposeful sampling generated 20 participants, snowball sampling generated one participant, and theoretical sampling generated two participants.

\subsection{Sampling Procedures}

Initially, purposeful sampling was used to allow for insightful inquiry. This helped the researcher to understand the phenomenon in-depth. Key employees from GESC and strategic planning leadership at Johnson Controls were purposefully selected for the relevance of their expertise to the research topic. They were "illuminative participants who will offer useful manifestation of the phenomenon of interest" (Patton, 2002, p.40). The initial list of participants included 54 employees. Due to workload, out of the 54 employees that were contacted, 20 were available to participate in the study at the end of purposeful sampling. Snowball sampling was used to locate information-rich key participants (Patton, 2002). Participants in the research were asked to recommend potential candidates that were suitable for the study. So, "by asking a number of people who else to talk with, the snowball gets bigger" (p.237) and hence, snowball sampling identified one additional participant that was added to the list for a total of 21 at the end of snowball sampling.

Once the conceptual categories were constructed from the data, theoretical sampling was used to obtain further data for the purpose of explicating the categories (Charmaz, 2006). Theoretical sampling was used because it "allows the researcher to discover the constructs that are relevant to this problem and population, and allows the researchers to explore the constructs in-depth" (Corbin \& Strauss, 2008, p.145). Constructs related to talent acquisition and investors emerged from the analysis. In order to explore the constructs in-depth, theoretical sampling was used to add two more participants to the study: one from human resources area and one from investor relations area.

\subsection{Interview Guide}

A total of 23 in-depth semi-structured interviews were conducted with individuals at Johnson Controls in strategic planning, public affairs, communications, and GESC functions. After an executive summary of the research was sent out to the participants, a sample of the interview guide followed via email. Interviews were conducted via conference calling. Each interview lasted from 30 minutes to 60 minutes. Interview questions were designed in light of the research questions (main and sub questions) and to ensure alignment between the two. Table 2 shows the alignment between the research questions and the interview questions.

Table 2. Research Questions to Interview Questions Map

\begin{tabular}{|c|c|}
\hline Research Question & Interview Question \\
\hline $\begin{array}{l}\text { How does } \mathrm{TBL} \text { influence } \\
\text { positioning } \\
\text { organization? (main question) }\end{array}$ & $\begin{array}{l}\text {-To be inductively answered through data analysis and document } \\
\text { reviews }\end{array}$ \\
\hline \multirow{2}{*}{$\begin{array}{l}\text { What does TBL mean to the } \\
\text { organization? } \\
\text { (sub-question one) }\end{array}$} & $\begin{array}{l}\text {-What is your understanding of TBL? Is there a system for TBL in } \\
\text { place at Johnson Controls? Can you give me an example of how } \\
\text { Johnson Controls uses the TBL as a competitive advantage? }\end{array}$ \\
\hline & $\begin{array}{l}\text {-Why do you think Johnson Controls emphasizes social responsibility, } \\
\text { environmental leadership, and economic prosperity in the work it } \\
\text { does? How important do you think this emphasis is to leadership of } \\
\text { the company? Do you think it is a top priority? Why or why not? }\end{array}$ \\
\hline
\end{tabular}


How does the organization incorporate TBL into the image?

(sub-question two)
-How do you describe the image of Johnson Controls? Can you describe a vivid picture of the "image" the company is trying to project to both internal and external stakeholders?

-How important do you think it is for Johnson Controls to be viewed as a "TBL driven organization"? Why?

How does Johnson Controls associate its "image" with TBL? Can you give me an example?
How does the organization use TBL image to differentiate its strategic position in the market?

(sub-question three)
-How does Johnson Controls strategically position itself in the market? In other words, what are the positioning strategies at Johnson Controls as an organization?

-What are some of the differentiation strategies used at Johnson Controls to achieve the desired strategic position in the market?

-How is "TBL image" used in the strategic positioning of Johnson Controls? Can you give me an example?

\section{Results}

In a narrative format, the findings resulted from the interviews articulated the meanings that were generated from the research questions. The transcribed interviews were coded using Corbin and Strauss (2008), Charmaz (2006), and Glaser and Strauss (1967) ground theory techniques. A streamlined codes-to-theory model for qualitative research guided the data analysis phase (Figure 1).

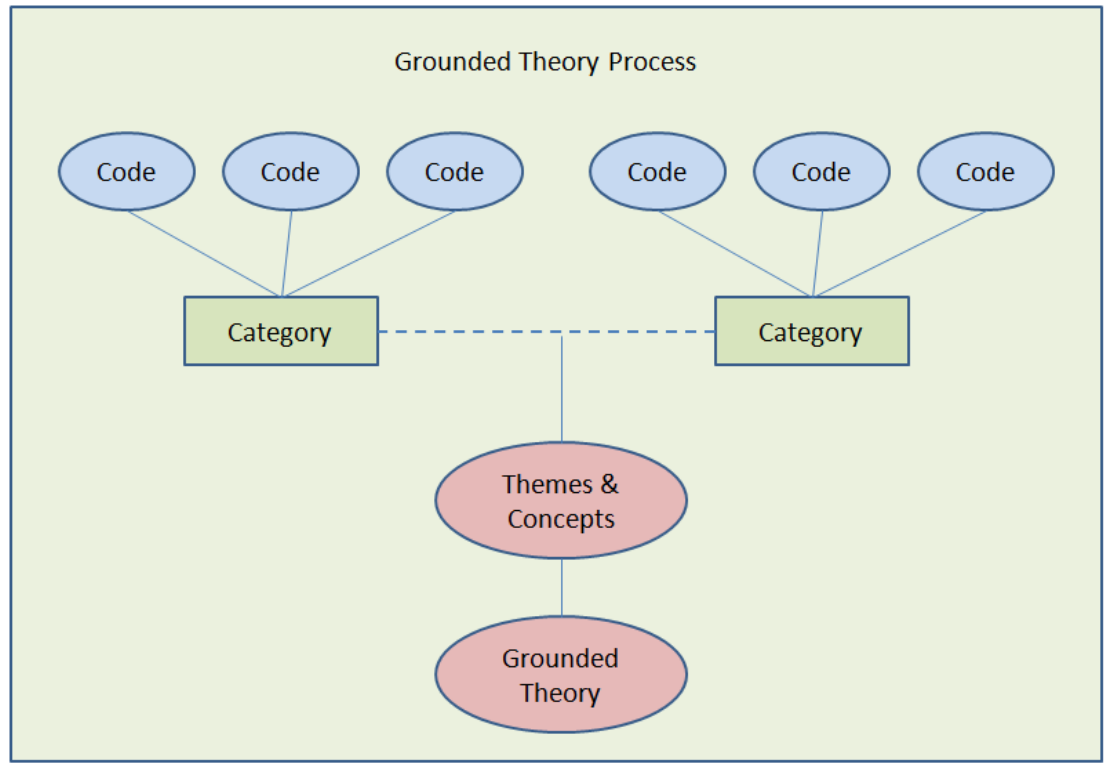

Figure 1. Grounded Theory Process

Adapted from Constructing Grounded Theory: A Practical Guide through Qualitative Analysis by R. Charmaz, 2006, p.11

Participants were asked about the importance of the TBL Image in Johnson Controls. Responses linked the importance of the TBL Image to talent acquisition and employee engagement. Interviewees indicated that the TBL Image is important in terms of attracting new talent to the organization. Johnson Controls has associated the social line of TBL (through talent acquisition and retention) with the building of shareholder value over the long run. The organization has indicated that attracting, motivating, and retaining highly qualified global management team who will drive a superior performance will build a shareholder value in the long-term (Johnson Controls, 2012c). Respondents pointed out that younger generations (new talents) are more attracted to organizations that support TBL 
as illustrated in the following sample responses:

RESP 10: I think it is important for Johnson Controls to occupy that position in the market. Younger generations want to work for companies that are making the world a better place, that have positive impact on communities. They don't want to work for companies that are out there to make a buck. I think we can make strong arguments that we are that type of a company in all of our three businesses. I think it is more important for the next generations that are entering the workforce than it is for people in the baby boom generation.

RESP 6: I also believe that the image is important because it helps us recruit good people and keep good people as long term employees. I think demographically that the younger people are tend to be more environmentally and socially aware and as they are thinking about career choices, I think they place a higher weight on sustainability than people like me who graduated in the 1980's. People tend to look for companies to work that have good results in this area. I think that will be increasingly important, not even now but in the future as we are coming up at a time where technical resources are and will be retiring. We will be fighting more and more for the best engineering and technical talents and I think it helps to helps to have that image when we are recruiting. It also helps with retention of people.

RESP 14: Because we realize that in order to be good corporate citizen and in order to attract the young talent that we need to grow this company, we need to represent ourselves as a company that is much more than just worrying about profitability. We need to represent that we are worried about the place that we live and where we work and what impact we have on the local communities, and we need to be worried about what impact our products have on the world. The fact that many of our products help the sustainability of the world in the form of energy efficiency or electric vehicles in batteries, the light weighting of our products that we put in the car; all of those factors we think important to attract talent to work here.

RESP 7: So in virtually every interview that I have with someone from a senior to junior level when they describe why they are interested in Johnson Controls, they say something rather ambiguous to the effect of..." I'm really impressed with your sustainability activity...you have solar panels or your building are very well LEED".

RESP 16: I think the other dimensions obviously: we are a large organization (160,000 people) we need to continue to be able to attract talent. Today, there is a war on talent. One of the things that attract people to our organization is that a company with a strong belief system of in the area of sustainability is more attractive as an employer than a company that isn't. From a talent aspect: being able to attract and secure talent into our business.

RESP 12: The most important thing is to do the right thing. But it is also important to show that we are doing the right thing in order to attract and retain talent for the company.

Respondents associated the TBL Image with the ability to acquire and retain talent. Like several other respondents, they particularly mentioned "young" talent. This suggests that age is a factor to be considered when evaluating the impact of the TBL Image on attracting new employees to the organization. As mentioned earlier and aligned with the annual financial report (prepared by Johnson Controls and presented to the United States Securities and Exchange Commission), the company stated that the business success depends on attracting and retaining qualified personnel. To this extent, the organization stated that:

"Our ability to sustain and grow our business requires us to hire, retain and develop a highly skilled and diverse management team and workforce. Failure to ensure that we have the leadership capacity with the necessary skill set and experience could impede our ability to deliver our growth objectives and execute our strategic plan. Any unplanned turnover or inability to attract and retain key employees could have a negative effect on our results of operations" (Johnson Controls, 2012c, p. 10 ).

Similarly, studies show the positive impact of other sustainability-related constructs on the attraction and retention of talent in the organization. Amonth those studies are Aguilera, Rupp, Williams, and Ganapathi (2007), Russo and Founts (1997), and Turban and Greening (1997).

Furthermore, employee engagement is a critical element in the success of Johnson Controls and one of the organization's core values for the 10-year marker (a set of strategic guideposts that were designed to guide the business to a long-term success). Johnson Controls stated that "As we grow, so will our people. We foster a culture that promotes excellent performance, teamwork, inclusion, leadership and growth. Our employee and leader diversity will mirror our global markets and population." (Johnson Controls, 2012a, p.1). Similar to the positive influence of sustainability on employee engagement, six respondents indicated that employee engagement is improved by the satisfaction from the feeling of being part of the community and the ability to contribute to the wellbeing of the environment and the society. The following excerpts are sample illustrations: 
RESP 7: I think employees have come to a more robust understanding of the value and benefits. So I see that folks get extra energy around working on behalf of good things for their environment or their communities, people get emotional and professional satisfaction out of feeling that they are part of that.

RESP10: We make sure that our employees think that this is a place where they can make an impact; they get rewarded, and recognized. That creates an employee brand that says Johnson Controls is a great place to work. You can make a career out of Johnson Controls that will meet your professional career goals.

\section{Discussion}

Respondents indicated that the TBL Image is positively associated with talent acquisition and employee engagement. Findings from the study informed the TBL Image Diagram, see Figure 2. The diagram shows that the TBL Image effects talent acquisition and employee engagement.

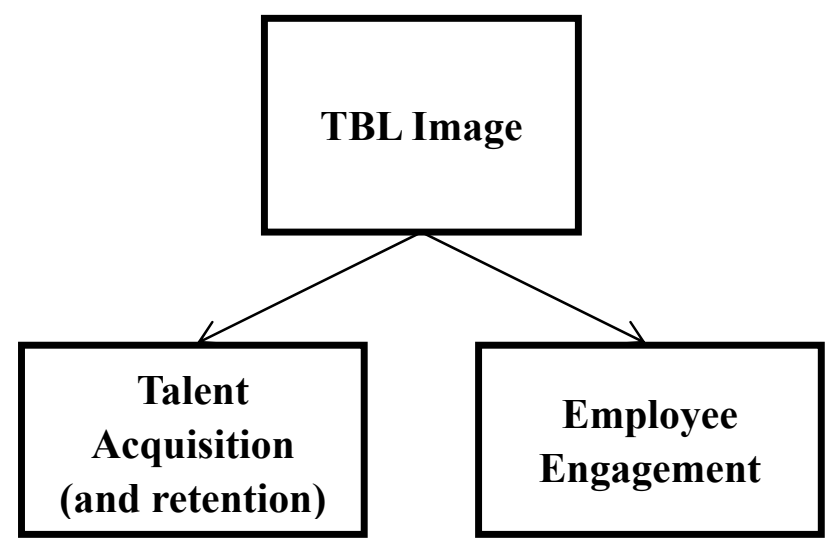

Figure 2. TBL Image Diagram

Respondents indicated that the TBL Image enables the organization to attract and retain talent. Participants also pointed out that younger generations (new talents) are more attracted to organizations that participate in the TBL space. Although relevant literature did not show significant empirical research linking TBL Image to talent acquisition and retention, literature contained several studies that showed a positive linkage between the image of other sustainability-related constructs and talent acquisition and retention. For example, studies showed that a good corporate reputation had an impact on attracting applicants and retaining competent employees (Dalton and Croft, 2003; Fombrun, 1996; Helm 2007; Jackson, 2004). Additionally, Husted and Salazar (2006) suggested that corporate social performance contributed to the attraction of highly qualified employees. Other studies suggested that sustainability in general had a positive influence on employee retention and on the recruitment process (Aguilera, Rupp, Williams, \& Ganapathi, 2007; Russo \& Founts, 1997; Turban \& Greening, 1997). Similar to findings from the literature, this study showed that image of TBL has a positive impact on talent acquisition and retention.

In terms of employee engagement, the term has been defined as the employees' willingness and ability to contribute to company success to "the extent to which employees put discretionary effort into their work in the form of extra time, brain power, and energy" (Towers Perrin, 2003, p. 3). High employee engagement increases the work-related performance by nearly one third (Luthans \& Peterson, 2001) while low employee engagement has contributed to an estimated $\$ 300$ billion loss in the U.S. economy (Saks, 2006). Respondents indicated that employee engagement is improved by the satisfaction from their feeling of being part of the local community and the ability to contribute to the wellbeing of the surrounding environment. As a critical element to business success, the literature revealed several studies that showed the impact of sustainability-related constructs on employee engagement. For example, Baradihi's (2011) qualitative study on the influence of sustainability on employee engagement has suggested that sustainability positively influences employee engagement with respect to the attitudes of employees about their work, the attitudes of employees about their employer, the behavior of employees at work in the form of influencing them to work harder to support the goals of the company, the reduction turn-over, and the effort of the employees to support the goals of the organization. Additionally, Glavas and Piderit (2009) proved a relationship between the perceived corporate citizenship and employee engagement. Moreover, Stairs (2005) suggested that employee engagement can be positively influenced by the employer's approach toward social and environmental issues. 


\section{Recommendations for Future Research and Limitations of the Study}

This study suggests two recommendations for future research. First, the nature of the qualitative research in this study generates a recommendation for future research to further develop the TBL Image Diagram into a model that can be tested using quantitative research methodology. The intent of the quantitative design is to establish statistical evidence by creating hypotheses developed from the theoretical propositions presented in this study (suggesting the positive influence of the TBL Image on talent acquisition 'and retention' and employee engagement). The second recommendation is to extend the scope of the study by exploring the relationship across other organizations and industries in order to determine the extent of generalization of the research results, which addresses a limitation of the study. This study is limited with respect to the inability to generalize. This inability is inherent in the qualitative research design (Patton, 2002). The single case study approach used in this research was done on one diverse global organization. Although the organization consisted of three distinct business groups, it would be interesting to understand the extent of generalization by testing the results on additional organizations.

\section{Summary}

The purpose of this paper was to explore TBL as an emerging phenomenon using grounded theory. In-depth semi-structured interviews were conducted with participants (employees in management and upper leadership positions at a global organization) that were selected using purposeful, snowball, and theoretical sampling. Results of the study suggest that the TBL Image has a positive influence on talent acquisition (and retention) and employee engagement. Following the grounded theory process, codes, categories, and concepts were developed systematically leading to the development of the TBL Image Diagram. This paper contributes to the sustainability scholarship by presenting new findings regarding TBL in light of the lack of empirical research on the topic in relevant literature. The study also contributes to the human resource scholarship by providing new insight into how TBL impacts the acquisition and retention of talent as well as employee engagement.

\section{References}

Aguilera, R., Rupp, C., \& Ganapathi, J. (2007). Putting the S back in CSR: A multi-level theory of social change in organizations. Academy of Management Review, 32(3), 836-863. http://dx.doi.org/10.5465/AMR.2007.25275678

Baradihi, F. (2012). An exploratory case study on the influence of sustainability on employee engagement. (Doctoral dissertation). Retrieved from https://my.ltu.edu/bbcswebdav/pid-298750-dt-content-rid 1352708_1/orgs/Dept_Mgt_DBA_Students/Baradihi\%20Dissertation\%20Presentation\%203\%2026\%2012.pdf

Bibri, M. (2008). Corporate sustainability/CSR communications and value creation: A marketing approach. (Master's thesis). Retrieved from WorldCat Dissertations. (OCLC: 747412678).

Charmaz, K. (2006). Constructing grounded theory: A practical guide through qualitative analysis. Los Angeles: Sage Publications Ltd.

Chen, Y. (2008). The driver of green innovation and green image - Green core competence. Journal of Business Ethics, 81, 531-543. http://dx.doi.org/10.1007/s10551-007-9522-1

Corbin, J., \& Strauss, A. (2008). Basics of qualitative research. Thousand Oaks, CA: Sage.

Dalton, J., \& Croft, S. (2003). Managing corporate reputation: The new currency. London: Thorogood.

Elkington, J. (1997). Cannibals with forks - Triple bottom line of 21st century business. Stoney Creek, CT: New Society Publishers.

Fombrun, C. (1996). Reputation: Realizing value from the corporate image. Boston: Harvard Business School Press.

Fombrun, C., \& Van Riel, C. (1997). The reputational landscape. Corporate Reputation Review, 1(1/2), 5-13. http://dx.doi.org/10.1057/palgrave.crr.1540024

Fraj-Andrés, E., Martinez-Salinas, E., \& Matute-Vallejo, J. (2008). A multidimensional approach to the influence of environmental marketing and orientation on the organization's organizational performance. Journal of Business Ethics, 88, 263-286. http://dx.doi.org/10.1007/s10551-008-9962-2

Glaser, B., \& Strauss, A. (1967). The discovery of grounded theory: Strategies for qualitative research. New Brunswick: Aldine Transaction. 
Glavas, A., \& Piderit, S. (2009, Winter). How does doing good matter? Effects of corporate citizenship on employees. Journal of Corporate Citizenship, 36, 51-70. http://dx.doi.org/10.9774/GLEAF.4700.2009.wi.00007

Goel, P. (2010). Triple bottom line reporting: An analytical approach for corporate sustainability. Journal of Finance, Accounting, and Management, 1(1), 27-42.

Haniffa, R., \& Cooke, T. (2002). Culture, corporate governance, and disclosure in Malaysian organizations. Abacus, 38(3), 317-349. http://dx.doi.org/10.1111/1467-6281.00112

Heikkurinen, P. (2010). Image differentiation with corporate environmental responsibility. Corporate Social Responsibility and Environmental Management, 17, 142-152. http://dx.doi.org/10.1002/csr.225

Helm, S. (2007). The role of corporate reputation in determining investor satisfaction and loyalty. Corporate Reputation Review, 10, 22-37. http://dx.doi.org/10.1057/palgrave.crr.1550036

Husted, B., \& Salazar, J. (2006). Taking Friedman seriously: Maximizing profits and social performance. Journal of Management Studies, 43(1), 75-91. http://dx.doi.org/10.1111/j.1467-6486.2006.00583.x

Jackson, K. (2004). Building reputational capital. Strategies for integrity and fair play that improve the bottom line. New York: Oxford University Press.

Johnson Controls. (2012a). 10-year Marker. Retrieved November 2, 2012 from http://www.johnsoncontrols.com/content/dam/WWW/JohnsonControls/be/global_workplace_solutions/transitio n/miscellaneous/ENG_10yr_DefsPoster_11x17_KEY.pdf

Johnson Controls. (2012b). Global Reporting Initiative Report. Retrieved November 1, 2012 from http://www.johnsoncontrols.com/content/us/en/sustainability/reporting/GRI_report.html

Johnson Controls. (2012c). Form 10-K. Retrieved October 26, 2012 from http://www.johnsoncontrols.com/content/dam/WWW/JohnsonControls/corporate/investors/2011/FY11_10-K__FINAL_for_web.pdf

Luthans, F., \& Peterson, S. (2001). Employee engagement and manager self-efficacy: implications for managerial effectiveness and development. Journal of Management Development, (21), 376-387.

Marshall, C., \& Rossman, G. (2006). Designing qualitative research. Thousand Oaks: Sage Publications.

Michelon, G. (2011). Sustainability disclosure and reputation: A comparative study. Corporate Reputation Review, 14(2), 79-96. http://dx.doi.org/10.1057/crr.2011.10

Patton, M. (2002). Qualitative research and evaluation methods. Thousand Oaks, CA: Sage.

Phelan-Ribera, K. (2011).Corporate social responsibility practices and financial performance over time for selected U.S. organizations. (Doctoral dissertation). Retrieved from WorldCat Dissertations. (OCLC: 759842398).

Roberts, R. (1992). Determinants of corporate social responsibility disclosure: An application of stakeholder theory. Accounting Organizations and Society, 17(6), 595-612. http://dx.doi.org/10.1016/0361-3682(92)90015-K

Rogers, K., \& Hudson, B. (2011). The triple bottom line: The synergies of transformative perceptions and practices of sustainability. OD Practitioner, 4(43), 3-9.

Russo, M., \& Fouts, P. (1997). A resource-based perspective on corporate environmental performance and profitability. Academy of Management Journal, 3(40), 534-559. http://dx.doi.org/10.2307/257052

Saks, A. (2006). Antecedents and consequences of employee engagement. Journal of Managerial Psychology, 21(7), 600-619. http://dx.doi.org/10.1108/02683940610690169

Shenkar, O., \& Yuchtman-Yaar, E. (1997). Reputation, image, prestige, and goodwill: An interdisciplinary approach to organizational standing. Human Relations, 50(11), 1361-1381. http://dx.doi.org/10.1177/001872679705001102

Stairs, M. (2005). Work happy: Developing employee engagement to deliver competitive advantage. Selection and Development Review, 5, 7-11.

Towers Perrin. (2003). Working today: Understanding what drives employee engagement. Retrieved from http://www.towersperrin.com/tp/getwebcachedoc?webc=hrs/usa/2003/200309/talent_2003.pdf

Turban, D., \& Greening, D. (1997). Corporate social performance and organizational attractiveness to prospective employees. Academy of Management Journal, 40, 658-672. http://dx.doi.org/10.2307/257057 